\begin{tabular}{lccc} 
VERSITA & GOSPODARKA & SUROWCAMI & MINERALNYMI \\
\hline \multirow{2}{*}{ Tom 28} & 2012 & Zeszyt 2 \\
& & DOI 10.2478/v10269-012-0015-1 &
\end{tabular}

\title{
Reduction of polycyclic aromatic hydrocarbons and nitrogen monooxide in combustion engine exhaust gases by clinoptilolite
}

\begin{abstract}
Introduction
The contribution of exhaust gases from combustion engines to environmental pollution amounts to $60 \%$ of the total contamination. Recently there has been an increased interest in utilization of zeolites for partial reduction of $\mathrm{NO}_{\mathrm{x}}, \mathrm{CO}$ and hydrocarbons in combustion engine exhaust gases. The catalysts used for detoxication of combustion engine exhaust gases are less effective during periods of relatively low temperatures, such as the initial cold-start period of engine operation. Some global research teams focused their efforts on the use of zeolites as sorbents and catalysts of noxious gases. The electrical field can be changed by modyfying the size of zeolite pores, and as a consequence, also the molecular sieve and selective sorption properties (Zeng et al. 2004; Reháková et al. 2003; Čeliščev et al. 1987). The properties and potential applications of the modified zeolitic forms depend on the method of sorption and the interaction of the host components from the zeolitic channels

* Associate Professors, Ph.D., University of Security Management in Košice, Department of Environmental Secutity, Slovak Republic; e-mail: jozef.macala@vsbm.sk

** Ph.D., Department of Manufacturing management, Faculty of Manufacturing Technologies of Košice with the seat in Prešov, Slovak Republic

*** Associate Professors, Ph.D., Department of Analytical Chemistry, Faculty of Sciences, P.J. Šafárik University of Košice, Slovak Republic

**** Ph.D., Department of Medically Chemistry, Biochemistry and Clinical Biochemistry of Faculty of Medical Science UPJŠ, Košice, Slovak Republik
\end{abstract}


and cavities. The incorporation of certain elements to the structure of zeolite improves its catalytic properties (Monticceli et al. 1999; Wiliams et al. 1995; Miller et al. 1993; Mizuno et al. 2000; Jacobs 1991).

The experiments investigated the ability of natural zeolite - clinoptilolite to reduce the level of hydrocarbons and nitrogen oxide in the exhaust gases of combustion engines. For the experiments, zeolite - clinoptilolite with the following properties was used:

- Mineralogical composition

- Clinoptilolite - 84\%,

- Illite $-4 \%$,

- Cristobalite $-8 \%$,

- Quartz traces,

- Fieldspar - 4\%,

- Carbonate minerále $-<0,5 \%$;

- Chemical composition

- $\mathrm{SiO}_{2}-65,0-71,3 \%$,

- $\mathrm{Fe}_{2} \mathrm{O}_{3}-0,7-1,9 \%$,

- $\mathrm{Al}_{2} \mathrm{O}_{3}-11,5-13,1 \%$,

- $\mathrm{MgO}-0,6-1,2 \%$,

- $\mathrm{CaO}-2,7-5,2 \%$,

- $\mathrm{Na}_{2} \mathrm{O}-0,2-1,3 \%$,

- $\mathrm{K}_{2} \mathrm{O}-2,2-3,4 \%$,

- $\mathrm{TiO}_{2}-0,1-0,3 \%$,

- $\mathrm{Si} / \mathrm{Al}-4,8-5,4 \%$.

- Partial exchange capacity $\mathrm{NH}_{4}{ }^{+} 0,7 \mathrm{~mol} \cdot \mathrm{kg}^{-1}$;

- Total exchange capacity $\mathrm{NH}_{4}{ }^{+} 1,2-1,5 \mathrm{~mol} \cdot \mathrm{kg}^{-1}$;

The influence of zeolite chemical treatment was studied. The chemical treatment included the incorporation of metal elements. Our analysis focused on components of exhaust gases containing polycyclic aromatic hydrocarbons with carcinogenic and mutagenic properties, for example benzo[a]pyrene and naphtalene.

The polycyclic aromatic hydrocarbons were analysed in the extract of both thermally-activated natural zeolite and chemically-modified zeolite subjected to amonnium chloride, cobalt chloride and copper sulfate treatment. The zeolite samples used were exposed to exhaust gases produced by the combustion engine of a SKODA Favorit model automobile with a $1300 \mathrm{~cm}^{3}$ motor and without a catalytic converter. The experimentation used 95-octane petrol.

Nitrogen monooxide concentration was measured simultaneously using a filter-sorption apparatus. 


\section{Materials and methods}

\subsection{Chemicals and materials}

The experiments investigated the influence of chemical treatment on zeolite sorption properties and on its catalytic activity. Samples of zeolite in its natural form, and chemicaly modified, of grain size 5-8 $\mathrm{mm}$, were used.

The contaminates samples were analysed by three independent methods - gas chromatography, high-efficiency liquid-chromatography and three-dimensional fluorescence analysis.

For identification of the polyaromatics, a 16-standard mixture of the most important polycyclic aromatic hydrocarbons was used in accordance with the American Environmental Protection Agency (EPA).

The standard solution of polycyclic aromatic hydrocarbons (PAHs) $\left(200 \mu \mathrm{g} \cdot \mathrm{ml}^{-1}\right.$ in methanol or methylene chloride) containing naphtalene, acenaphtylene, acenaphtene, fluorene, phenantrene, anthracene, fluoranthene, pyrene, chrysene, benzo[a]anthracene, benzo[a]pyrene, benzo[b]fluoranthene, benzo[k]fluoranthene, dibenzo[a,h]anthracene, benzo[g,h,i]perylene and indenopyrene as well as standard solutions containing individual polyaromatics were purchased from Supelco (Bellefonte, USA).

All other reagents and chemicals were either HPLC or analytical grade. Acetonitrile, methanol and 2-propanol were obtained from Merck (Darmstadt, Germany). Ammonium chloride, cobalt chloride and copper sulphate were purchased from Lachema (Brno, Czech Republic). Solid-phase cartridges of C18 Strata were obtained from Phenomenex (Phenomenex, USA).

\subsection{Zeolite treatment}

The adsorption characteristics of zeolites are dependent upon the detailed chemical/ /structural makeup of the adsorbent. The $\mathrm{Si} / \mathrm{Al}$ ratio and the cation type are influential in adsorption. The thermal treatment and the level of dehydration may also affect the final properties of the adsorbent (Ackley 1991). The clinoptilolite has a two-dimensional system of channels. The incoming openings proportions are $0,4 \times 0,55 \mathrm{~nm}$ (Barrer 1987). In the experiments, the clinoptilolite was used in a natural form, thermally activated at $270^{\circ} \mathrm{C}$ and chemically modified. The experiments used zeolite which was $84 \%$ clinoptilolite. [By literature (Patent Cooperation Treaty 1997; Japanese Patent Office 1993) to the sturcture of the zeolite can to be incorporate metal cations by water solution of this cations effect (the meaning of this sentence is unclear)]. The clinoptilolite with a grain size of 5-8 $\mathrm{mm}$ from Nižný Hrabovec (Slovakia) was modified to an ammonium form by the ion-exchange process using an ammonium chloride water solution with a concentration of $1 \mathrm{~mol} \cdot \mathrm{dm}^{-3}$. The clinoptilolite was treated with ammonium chloride to obtain an $\mathrm{NH}_{4}{ }^{+}$type of ion-exchanged zeolite. To obtain the $\mathrm{NH}_{4}{ }^{+}$type, $700 \mathrm{~g}$ of the natural zeolite-clinoptilolite sample was washed for 24 hours with an ammonium chloride solution and dryed at $270^{\circ} \mathrm{C}$. The ammo- 
nium type of clinoptilolite was used to prepare the cobalt zeolite modification. $700 \mathrm{~g}$ of the $\mathrm{NH}_{4}{ }^{+}$zeolite was washed with a $0.5 \mathrm{~mol} \cdot \mathrm{dm}^{-3}$ solution of $\mathrm{CoCl}_{2}$ for 24 hours at $24^{\circ} \mathrm{C}$. $\mathrm{The} \mathrm{Cu}^{2+}$ clinoptilolite modification was prepared in a similar way. Another $700 \mathrm{~g}$ of the zeolite sample was decanted with distilled water, and the $\mathrm{NH}^{4+}$ zeolite type was prepared. The $\mathrm{NH}^{4+}$ zeolite was dried at $270^{\circ} \mathrm{C}$, allowed to cool and washed with a $0.5 \mathrm{~mol} \cdot \mathrm{dm}^{-3}$ $\mathrm{CuSO}_{4}$ solution. After drying at $270^{\circ} \mathrm{C}$, the samples were preapared for experimental measurements.

All the samples of thermally-activated and chemically-modified zeolites with a mass of $650 \mathrm{~g}$ intended for PAH analysis were subsequently placed into the filter-sorption apparatus and exposed to exhaust gases under identical conditions (1500 rev/min). Contamination for PAH analysis began with the cold start and continued for 15 minutes. The apparatus had a stainless steel coat in which a net pipe was placed. The exhaust gases could flow through the net pipe which was filled with granular zeolite. After unscrewing the flange, another sample could be exposed to the exhaust gases. The filter sorption apparatus was placed at the end of the exhaust system of the mobile source of exhaust gases.

\subsection{Extraction procedure}

$30 \mathrm{~g}$ of each contaminated and uncontaminated zeolite sample were used for the PAHs multiple ultrasonic extraction $(4 \times 25 \mathrm{ml}$ toluene, 1 hour $)$. The resulting extract solutions were dried using a rotary evaporator, and the residues were dissolved in 2-propanol for the subsequent solid-phase extraction (Kicinski et al. 1989; Götze et al. 1991).

The solid-phase extraction was performed using C18 solid-phase cartridges (Strata $500 \mathrm{mg}$, Phenomenex, USA). After elution by an acetonitrile-methanol mixture, the solution was ready for chromatographic analysis. For the fluorescence analysis, the extract was diluted with methanol at a ratio of 1:10 000 .

\section{Analysis}

The GC analysis of PAHs was accomplished with a Shimadzu GC-14A gas chromatograph equipped with a flame ionization detector. The carrier gas was nitrogen at a constant flow of $1 \mathrm{ml} / \mathrm{min}$. A capillary column SPB-5 (Supelco, Switzerland) $30 \times 0,75 \mathrm{~mm}$, $1 \mu \mathrm{m}$ film thickness was used as an analytical column. Initial column temperature was held for $2 \mathrm{~min}$ at $60^{\circ} \mathrm{C}$, programmed at $10^{\circ} \mathrm{C} / \mathrm{min}$ to $320^{\circ} \mathrm{C}$ which was held for $5 \mathrm{~min}$. The injector and detector temperatures were maintained at $220^{\circ} \mathrm{C}$ and $320^{\circ} \mathrm{C}$, respectively. Injection of $2 \mu 1$ of the extract was performed with a microsyringe (Hamilton, USA).

HPLC separation was performed on Thermo Separation Products AS 3000, USA liquid chromatograph equipped with a fluorescence detector (Spectra System FL 3000, USA) at $40^{\circ} \mathrm{C}$. Lichrospher PAH column $(25 \mathrm{~cm} \times 4 \mathrm{~mm}, 5 \mu \mathrm{m}$, Merck $)$ was used for chromatographic separation. 
Mixtures of acetonitrile-methanol-water $(20: 40: 20, \mathrm{v} / \mathrm{v} / \mathrm{v})(\mathrm{A})$ and acetonitrile (B) of varying compositions were used as mobile phases at a flow rate of $1 \mathrm{ml} / \mathrm{min}$. The elution profile was: A for $1 \mathrm{~min}$, then linear gradient to $100 \%$ B over $30 \mathrm{~min}$.

Synchronous spectra were scaned by a luminescent spectrofluorimeter Perkin Elmer LS55 in the range of excitant wavelengths $250-500 \mathrm{~nm}$ simultaneously with the movement of the excitant and emissive monochromator with the wavelength difference $\Delta \lambda=10-200 \mathrm{~nm}$, increment $\Delta \lambda=10 \mathrm{~nm}$, crevice $\mathrm{Ex} / \mathrm{Em}=5 / 10 \mathrm{~nm}$, with silica cuvette $1 \mathrm{~cm}$, monochromator scan speed $1200 \mathrm{~nm} / \mathrm{min}$. Synchronous spectra were presented as contour maps as the dependence of the fluorescence intensity on the excitant wavelength and the defined difference in wavelength between the monochromators $F=f\left(\lambda_{\text {ex }} ; \Delta \lambda\right)$. The same fluorescence intensity points link the contours. The value of the contours representes $5 \%$ of the global fluorescence.

\section{Results and discusion}

Polycyclic aromatic hydrocarbons (PAHs) are an excelent group of compounds for investigation by fluorescent spectroscopy because of their strong fluorescence (Andrade et al. 2000; Luo et al. 2005). Contour maps (Fig. 1) of the contaminated and clean zeolite extracts were distinctively different. The more abundant contour map refers to the presence of polycyclic aromatic hydrocarbons which were absorbed by ammonium modification of zeolite. Fluorescence centres $\left(\lambda_{\text {ex }} / \Delta \lambda\right) 280-300 / 140 \mathrm{~nm}, 298 / 120 \mathrm{~nm}, 398 / 70 \mathrm{~nm}$ correspond to their fluorescence. The contour map of zeolite modified by ions $\mathrm{Co}^{2+}$ and $\mathrm{Cu}^{2+}$ does not apart the noncontaminate. The respective polycyclic aromatic hydrocarbons were analysed by HPLC and GC methods. The sorptive ability of natural zeolite for some PAHs present in exhaust gases was proved. The extracts of noncontaminated zeolite and zeolite exposed to exhaust gases were compared. The contaminated zeolite extract contained some polycyclic aromatic hydrocarbon-phenanthrene, pyrene, benzo(b)fluoranthene, benzo(a)pyrene and benzo(g,h,i)perylene.

The analysis of the extract was repeated after the zeolite chemical treatment to $\mathrm{NH}_{4}{ }^{+}$ type and after its contamination. On the basis of GC and HPLC analysis of the extract, it is possible to state that the treatment increased the sorption properties towards PAHs. In the extract of the contaminated $\mathrm{NH}_{4}{ }^{+}$zeolite type, the polyaromatics with high molecular weight were found-fluorene, phenanthrene, pyrene, benzo(a)anthracene, chrysene benzo(b)fluoranthene, benzo(k)fluoranthene, benzo(a)pyrene, dibenzo(a,h)anthracene, benzo(ghi)perylene.

The following experiments focused on the influence of chemical modification of zeolites by copper sulfate and cobalt chloride on their sorptive properties. After contamination of the chemically-modified zeolites placed in the filter-sorption apparatus, the gas chromatography analysis was carried out using the previously described procedure. Comparison of results showed that no carcinogenic polycyclic aromatic hydrocarbons, present in extracts of natural 


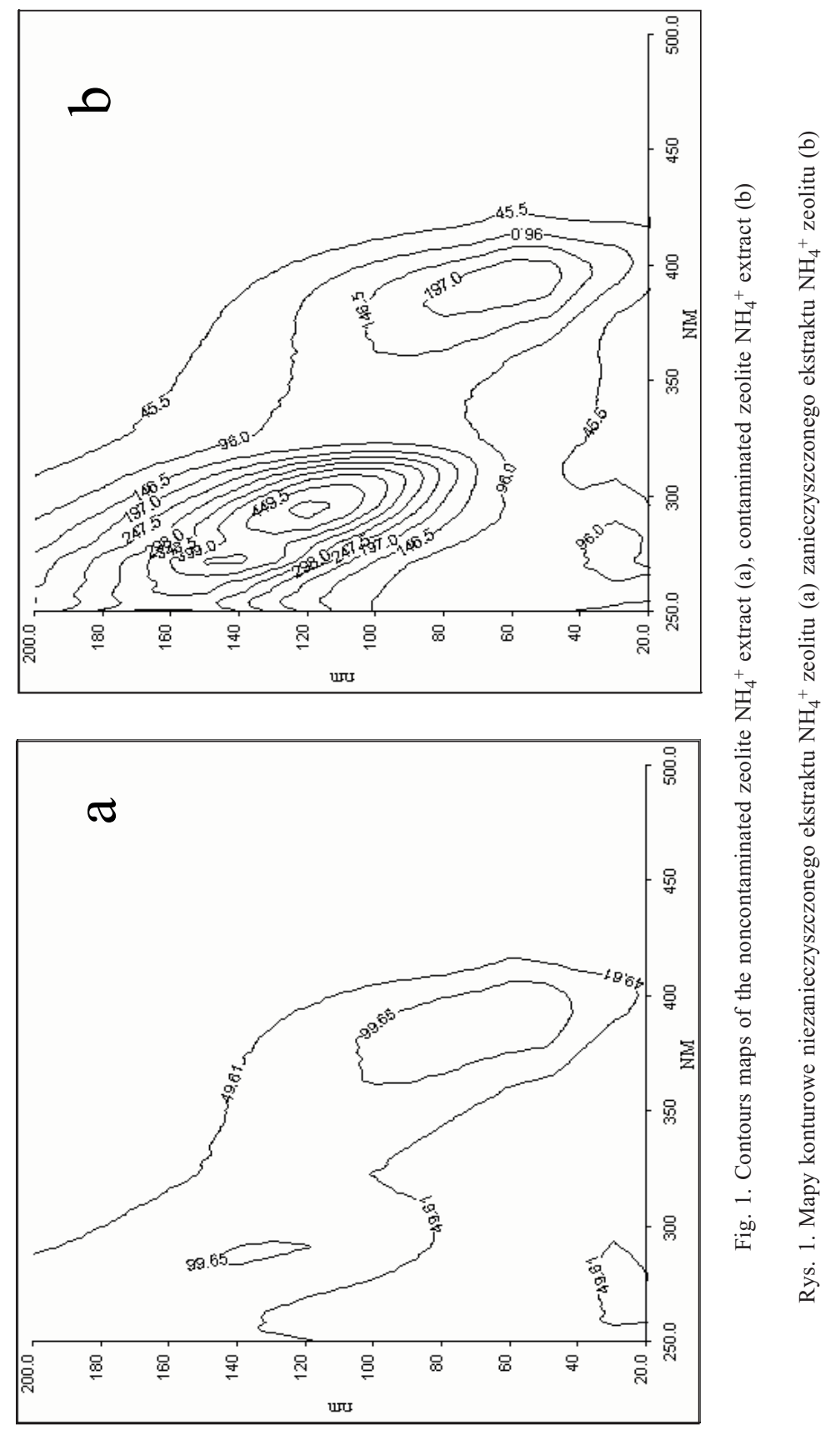


and $\mathrm{NH}_{4}^{+}$type of zeolite, were found in the $\mathrm{Co}^{2+}$ and $\mathrm{Cu}^{2+}$ extracts. The subsequent experiment investigated sorption of nitrogen monooxide on natural and modified zeolites and their presumed catalytic activity. The level of NO was measured in exhaust gases which passed through the filter-sorption apparatus filled with natural zeolite and thermically- and chemically-modified zeolites. The initial measurements were carried out with natural zeolite samples. After the preliminary measurements, the zeolite samples were thermally activated and chemically modified by ammonium chloride, cobalt chloride and copper sulfate. All the measurements of NO concentration were conducted using the vehicle SKODA 120 with an internal combustion engine as a source of exhaust gases.

The concentration of NO was recorded in periodic time intervals at the inlet and outlet of the filter-sorption apparatus, filled with zeolite of grain size 5-8 mm, under identical conditions ( $800 \mathrm{rev} / \mathrm{min}$ ). The registered values allowed us to calculate the efficiency of the filter-sorption apparatus. The efficiency determined was presented in a graphical form (Fig. 2, 3, 4, 5). The efficiency of natural zeolite ranged between $19 \%$ and $25 \%$. The mean efficiency of the filter-sorption apparatus with thermally-activated zeolite $\left(270^{\circ} \mathrm{C}\right)$ was $31 \%$. After the modification with $\mathrm{NH}_{4} \mathrm{Cl}$ the efficiency increased to $59 \%$. The dependence of the filter-sorption apparatus on the time after the modification of natural zeolite is evident from

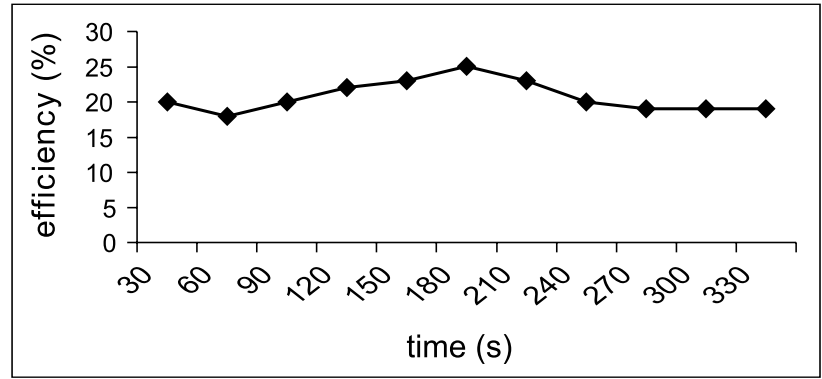

Fig. 2. Time dependence of the filter-sorption apparatus efficiency with natural zeolite

Rys. 2. Zależność urządzenia z filtrem sorpcyjnym z naturalnym zeolitem od czasu wydajności

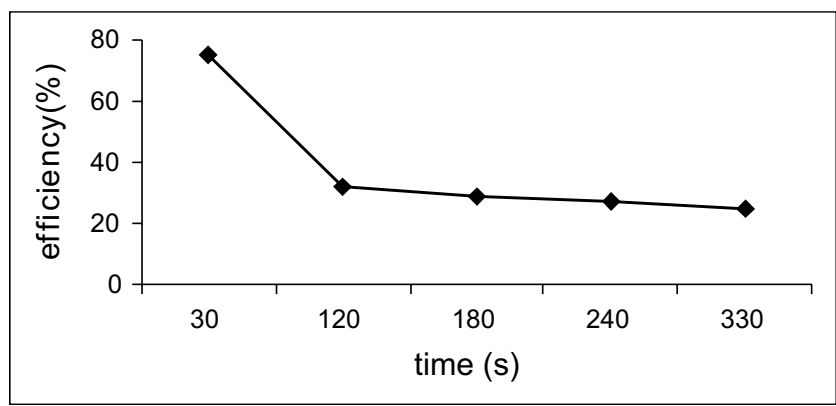

Fig. 3. Time dependence of the filter-sorption apparatus efficiency with thermally-activated zeolite

Rys. 3. Zależność urządzenia z filtrem sorpcyjnym z termicznie aktywowanym zeolitem od czasu wydajności 
120

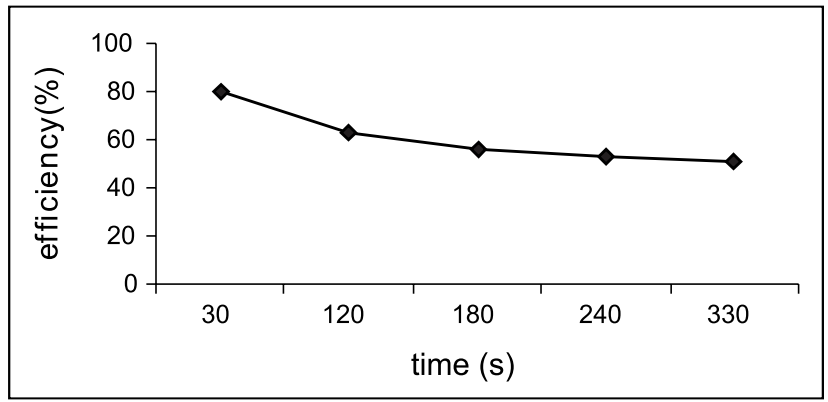

Fig. 4. Time dependence of the filter-sorption apparatus efficiency after the zeolite chemical treatment by $\mathrm{NH}_{4} \mathrm{Cl}$

Rys. 4. Zależność urządzenia $\mathrm{z}$ filtrem sorpcyjnym z zeolitem po obróbce chemicznej przez $\mathrm{NH}_{4} \mathrm{Cl}$ od czasu wydajności

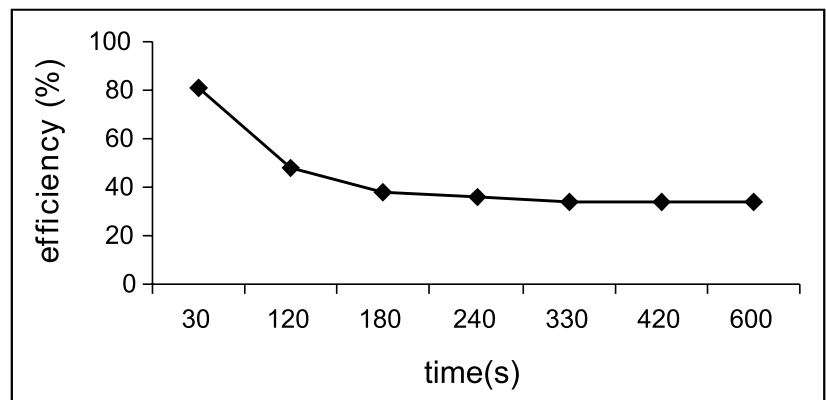

Fig. 5. Time dependence of the filter-sorption apparatus efficiency after the zeolite chemical treatment by $\mathrm{CoCl}_{2}$

Rys. 5. Zależność urządzenia z filtrem sorpcyjnym z zeolitem po obróbce chemicznej przez $\mathrm{CoCl}_{2}$ od czasu wydajności

Figure 4. After 30 seconds, the curve shows a descending trend. The peak efficiency at $30 \mathrm{sec}$ was $80 \%$. Table 1 presents efficiency values for various zeolite samples. It shows that with the untreated zeolite, the highest efficiency (25\%) was reached at 180 seconds, and then showed a gradual decrease. A moderate increase in mean efficiency was achieved by thermal treatment. A relatively high efficiency (75\%) was recorded at 30 seconds, with a subsesquent, rapid decrease to only $25 \%$ at 270 seconds. The ammonium chloride treatment caused a marked increase in efficiency to $59 \%$.

The highest mean values were recorded for the ammonium form of zeolite. Additional experiments investigated the influence of incorporating cobalt cations to zeolite structure. The mean efficiency reached with this modification was $46.4 \%$. We can assume that in this case, under the influence of cobalt cations incorporated in the pores of zeolite, not only NO sorption but also conversion of nitrogen oxide to nitrogen could be expected.

$$
2 \mathrm{NO} \rightarrow \mathrm{N}_{2}+\mathrm{O}_{2}
$$


Efficiency of $\mathrm{NO}$ adsorption from exhaust gas using various zeolite samples as a function of time

TABELA 1

Zmiana wydajności w czasie adsorpcji $\mathrm{NO}$ z gazów spalinowych przy wykorzystaniu różnych próbek zeolitu

\begin{tabular}{||c|c|c|c|c||}
\hline \multicolumn{5}{|c|}{ Efficiency of NO adsorption by zeolite (\%) } \\
\hline time (s) & natural & thermally activated & NH $_{4}$-form & Co-modified \\
\hline \hline 30 & 20 & 75 & 80 & 81 \\
69 & 18 & 54 & 69 & 69 \\
90 & 20 & 32 & 65 & 59 \\
120 & 22 & 32 & 63 & 48 \\
150 & 23 & 30 & 59 & 32 \\
180 & 25 & 29 & 56 & 36 \\
210 & 23 & 29 & 55 & 36 \\
240 & 20 & 27 & 53 & 34 \\
270 & 19 & 25 & 52 & 34 \\
300 & 19 & 25 & 51 & 34 \\
330 & 19 & 25 & 51 & 34 \\
360 & 19 & 25 & 51 & 34 \\
\hline
\end{tabular}

According to the literary sources (Obalová, Bernauer 2003), if a catalyst is present, $\mathrm{N}_{2} \mathrm{O}$ produced at combustion is converted according to the following formula before its oxidation to NO:

$$
\begin{gathered}
\mathrm{N}_{2} \mathrm{O} \rightarrow \mathrm{N}_{2}+1 / 2 \mathrm{O}_{2} \\
\mathrm{~N}^{2+} \leftrightarrow \mathrm{N}^{0} \\
\mathrm{Co}^{2+} \leftrightarrow \mathrm{Co}^{3+}
\end{gathered}
$$

The highest efficiency (87\%) of the filter-sorption apparatus was registered at 15 seconds. Between 15 and 270 seconds, the efficiency was maintained at $34 \%$. After that, the efficiency showed no further changes. $\mathrm{NO}$ measurements using the $\mathrm{CuSO}_{4}$ zeolite modification showed that, contrary to the previous measurements, the concentration of nitrogen monooxide in exhaust gases was increased at the apparatus outlet. There is an explanation for this fact. Deamonization of the sample at $270^{\circ} \mathrm{C}$ is not complete. Some residual $\mathrm{NH}_{4}^{+}$cations remain in zeolite channels and are oxidized to nitrogen monooxide by the catalytic effect of $\mathrm{Cu}^{2+}$.

Our experiments confirmed the ability of natural zeolite-clinoptilolite to absorb some polycyclical aromatic hydrocarbons. The results obtained allow us to to state that natural zeolite-clinoptilolite is a prospective material for reducing PAHs and nitrogen monooxide levels in combustion engine exhaust gases. 
As far as the ability of zeolite to reduce the content of NO in exhaust gases is concerned, the best results were reached for zeolite treated with amonnium chloride and cobalt chloride. Based on the results of this study and the reasonable price of natural zeolite, one can envisage its use in the automobile industry for the purpose of reducing the content of PAHs and NO in the exhaust gases, particularly during the cold-start period of engine operation when the conventional catalyst is not effective.

\section{REFERENCES}

A ckley M.W., Ralph T.Y., 1991 - Ind. Eng. Chem. Res. 30.

Andrade-Eiroa A., et al., 2000 - Analusis 28. 148 p.

B arrer R.M., 1987 - Zeolites and Clay Minerals as sorbent and Moleculars Sieves, Academic Press, London, New York, San Francisco.

Coun tw a y R.E., 2003 - Polycyclic aromatic hydrocarbon distributions and associations with Organic matter in surface watwers of the York River, VA Estuary. Organic Geochemistry 34. p. 209-224.

Čeliščev et al. 1987 - Čeliščev N.F., Berenštein B.G., Volodin B.F., 1987 - Ceolity - novyj tip mineral'novo syrja, Nedra, Moskva, p. 103-104.

Götze et al. 1991 - G ö tze H.J., S c hne i d e r J., Her zo g H.G., Frezen i u s J., 1991 - Anal.Chem. 340.27 p.

J a c ob s P.A., 1991 - Zeolite Chemistry and Catalysis, Amsterdam - Oxford - New-York, Elsevier.

Japanese Patent Office, 1999 - 05321655 A, 7. 12. 1993.

JiJi et al. 1999 - Ji J i R.D., C o o per G.A., B o o ks h K.S., 1999 - Anal. Chim. Acta 397.61 p.

Kicinski et al. 1989 - Kicins ki H.G., A damek S., Kettrup A., 1989 - Chromatographia 28. 203 p.

Luo et al. 2005 - Lu o X.J., Chen S.J., Mai B.X., Y ang Q.S., Sheng G.Y., F u J.M., 2005 - Environmental Pollution.

Me i e r W., 1986 - Zeolites and Zeolite-like Materials, Proc. 7th. Int. Zeolite Conf. Elsevier, Tokyo.

Miller S., et al. (Engelhard Corporation), 1993 - PCT/US93/11312 (F01N 3/20, 3/28).

Mizuno et.al. Uited States Patent, 2000 - US 006029441 A.

Monticelli et al. 1999 - Monticelli O., Loenders R., Jac obs P.A., Martens J. A., 1999 - Environmental $21.215 \mathrm{p}$.

Obalová L., B ernauer B., 2003 - Chem. Listy 97. 255 p.

Patent Cooperation Treaty, 1997 - US 96/15992, 26. jún 1997.

Patra D., Mistra A.K., 2002 - Total synchronous fluorescence scan spectra of petroleum products Anal. Bioanal. Chem. 373. 304 p.

Reháková et al. 2003 - Reháková M., Čuvanová S., Gava l’ová Z., R i már J., 2003 - Chem. Listy 97. 260 p.

Reháková et al. 2003 - Reháková M., Chmielewska E., Nagyová S., 2003 - Solid State Phenomena Vols. 90 p.

S ant an a R., Padron Sanz J., 2000 - Analusis, 28. 710 p.

Szabová et al. 2005 - Szabová T., Zahuranec E., Koščová M., 2005 - Vplyv aplikácie zeolitu na obsah t'ažkých kovov v pôdach a ich bioprístupnost'. Agrochémia, roč. 9 (45), č. 2, p. 19-22.

Szabová et al. 2005 - S zabová T., Búgel M., K o ščová M., 2005 - Možnosti zníženia obsahu t’ažkých kovov v pôdach aplikáciou zeolitu. Agrochémia, roč. 9 (45), č. 2, p. 7-9.

Willi a ms P., Horne P., 1995 - Journal of Analytical and Applied Pyrolysis, 31. 39 p.

Zheng et al. 2004 - Z heng G., H u ang W.H., L u X.H., 2004 - Environmental Informatics Archives, 2.711 p.

Zheng et al. 2005 - Zheng G., Huang W.H., Lu X.H., 2004 - Environmental Informatics Archives, 2. p. 711-721. 
REDUKCJA WIELOPIERŚCIENIOWYCH WĘGLOWODORÓW AROMATYCZNYCH I TLENKÓW AZOTU W GAZACH WYDECHOWYCH SILNIKA SPALINOWEGO PRZY UŻYCIU KLINOPTYLOLITU

\section{Słowa kluczowe}

Klinoptylit, wielopierścieniowe węglowodory aromatyczne (WWA), szkodliwe gazy, tlenek azotu, chromatografia gazowa, chromatografia cieczowa, widmo fluorescencyjne

\section{Streszczenie}

Przedmiotem niniejszej pracy było zbadanie zeolitu jako sorbentu toksycznych gazów. Wystąpienia dwóch warstw zeolitu zawierających wtrącenia aktywnego klinoptylitu można spotkać w okolicach Nižnego Hrabovca w Republice Słowackiej. Przedstawione badania dotyczą zdolności tego naturalnego zeolitu do redukcji wielopierścieniowych węglowodorów aromatycznych (WWA) i redukcji emisji tlenków azotu z układu wydechowego silnika. Gazy wydechowe z silników spalinowych zawierają toksyczne składniki, takie jak tlenek węgla, tlenki azotu i węglowodory. Wielopierścieniowe węglowodory aromatyczne (WWA) wywierają szkodliwy wpływ na zdrowie istot żywych. Wykonane eksperymenty koncentrowały się na ocenie potencjalnej redukcji tych toksycznych gazów poprzez sorpcję i właściwości katalityczne naturalnego zeolitu. Obserwowano także możliwości korekty procesu chemicznego, w tym poprzez zastosowanie niektórych związków pierwiastków metalicznych Prowadzone analizy chemiczne z wykorzystaniem niezależnych technologii miały na celu obserwację sorpcji WWA o kancerogennych właściwościach na testowanym naturalnym zeolicie. Doświadczenia wykazały, że chemiczna modyfikacja poprawia właściwości sorpcyjne i katalityczne natualnego zeolitu. Analizowano WWA w zanieczyszczonym, termicznie aktywowanym naturalnym zeolicie oraz w modyfikowanym zeolicie powstałym po jego przepłukaniu w chlorku amonu, chlorku kobaltu i siarczanie miedzi. W pracy przedstawiono również wyniki pomiarów NO uzyskanych z badań filtra sorpcyjnego samochodu.

REDUCTION OF POLYCYCLIC AROMATIC HYDROCARBONS AND NITROGEN MONOOXIDE IN COMBUSTION ENGINE EXHAUST GASES BY CLINOPTILOLITE

$$
\text { Key words }
$$

Clinoptilolite, polycyclic aromatic hydrocarbons (PAHs), noxious gases, nitrogen oxide, gas chromatography, liquid chromatography, fluorescence spectrum

\section{Abstract}

The subject of this work was the investigation of zeolite as a sorbent of toxic gases. In Nizny Hrabovec in the Slovak republic, two layers of zeolite with the active component clinoptilolite can be found. The study presented here investigated the ability of this natural zeolite to reduce polycyclic aromatic hydrocarbons (PAH) and NO emissions from engine exhaust. Exhaust gases from combustion engines include toxic components such as carbon monoxide, nitrogen oxides and hydrocarbons. Polycyclic aromatic hydrocarbons (PAH) are a component of hydrocarbons causing harmful influence on life forms. The experiments focused on the potential reduction of these toxic gases based on the sorption and catalytic properties of natural zeolite. Also observed was the influence of chemical adjustment including incorporation of certain metal elements. Chemical analysis by mutually independent technologies served to observe the sorption of PAH with carcinogenic properties on the natural zeolite tested. The experiments showed that chemical modification improved the sorption and catalytic properties of natural zeolite. The PAH were analysed in an extract of the contaminated, thermally-activated natural zeolite and modified zeolite after washing with ammonium chloride, cobalt chloride and copper sulphate. The study also presents results of NO measurements obtained by testing the filter-sorptive automobile system. 